\title{
Disappearing the American Dream... Fire Sales and Emergency Managers in the Heartland
}

\author{
By Julie Johnson*
}

Public space exists as part of the democratic process. Whether that space is architectural and relates to real estate, institutional in the instance of public schools, or social with respect to forums and programs that service and support entire communities, the presence and vitality of space for the public is critical to the communication and conflict ultimately required to ensure the survival of a democracy. Without this space critical thought, discourse and protest are stifled. As a visual artist and sculptor, my research questions the politics of artistic and social space in an age of globalization and privatization. My studio practice probes visual ways to represent the increasing disappearance of public space and the social ramifications attendant to that. My scholarly work is anchored in research and works by Rosalyn Deutsche, Evictions: Art and Spatial Politics, and Branko Milanovic, lead economist at the World Bank's research division and author of The Haves and the Have-Nots. My research also includes selected works on globalization and articles detailing the role of emergency managers in determining fiscal policy and economic strategy at the local level within the United States. This arc of inquiry has produced questions that include but aren't limited to the following: In light of the pressing global economic issues of recent years, what causes the current and unusual reimagining of what constitutes a postrecession economic emergency at the local level? What role do current U.S. state-level governments now have in determining how and for whom those fiscal emergencies are mediated at the local level? My work investigates the recent and vastly expanded role of emergency managers now routinely installed by Michigan state governor Rick Snyder. I question whether this practice also serves as a test for other states seeking, through the politicization and privatization of public space, to diminish the influence of a vibrant and at times contentious public, and the heretofore democratically determined territory that it occupies.

${ }^{*}$ Master of Fine Art Candidate 2015, Michigan State University, USA. 
"Every epoch in fact, not only dreams the one to follow, but in dreaming, precipitates it's awakening."

Walter Benjamin, The Arcades Project: Exposé of 1935

What are the connections between art, spatial politics, and economic strategies that shift public enterprise into private control? How do the politics of territory influence the disappearance of democratic space in the global economic environment? My research and practice concern themselves with the recent appointments of emergency managers in Michigan, and how these appointments alter the democratic processes that fundamentally define a republic. Prior to the housing crisis I was employed in the mortgage industry. What I observed there caused me to re-examine connections between local crises and market-centered global economic systems. As a sculptor, it was natural for me to question the spaces art shares with markets and economies, as well as explore the possibilities that art might possess to make more visible these places as contested territories. As artists, how should we locate ourselves, and our work, in a globalized world struggling with a new set of rules for survival? Is it important that we do so? Does our self-identification as artists affect how we regard the rapidly shifting global landscape?

In her book, Evictions: Art and Spatial Politics, Deutsche stated that, "The new public art was defined as art that takes the form of functional objects placed in urban settings or... as art that helps design urban spaces." She added, "Moreover, the promotion of the new public art itself took place within a broader context, accompanying a massive transformation in the uses of urban space--the redevelopment and gentrification of cities engineered throughout the 1980 s as the local component of global spatioeconomic restructuring" (Deutsche, 2002, pp.259-260). What Deutsche identified as occurring in New York City in the 1980s, now occurs in the promotion of new market-driven economies eclipsing previous models of capitalism that at least sought to minimally balance social and market concerns.

The shift from Keynesian capitalism to the more aggressive neoliberal model is characterized by "...deregulation (of the economy), liberalization (of trade and industry), and privatization (of state owned enterprises)," or DLP, resulting in an upward redistribution of wealth, and a reversal of the downward redistribution of wealth that preceded it (Steger \& Roy, 2010, p.14). This paper examines how global economic strategies, specifically those promoting privatization, and managed governance, are locally implemented in ways that impact both the art world, and democratic spaces and processes. This paper does not intend to prescribe a position for art or artists. Rather, it is my hope that artists will begin to think more critically about the role their art plays, as well as the roles that they will play as artists in a world with new rules.

Richard Lloyd, in Neo-Bohemia: Art and Commerce in the Postindustrial City, examined how artists and the larger creative community are directly connected to the continued development and spread of neoliberal global capitalism through the restructuring of urban space via gentrification (Lloyd, 2010, p.18). Observing artist's communities, or "bohemias" as he refers to 
them, from the nineteenth century until the present, Lloyd explained how these creative spaces have changed, and now directly connect the art world to neoliberal economic policy and expansion. He cited the significant increase of those who identified themselves as part of a class of creative culture producers and concluded as credible, "...the idea of an expanded cultural economy that affects employment as well as consumption" (Lloyd, 2010, p.68).

These connections both conceal and create problems for Lloyd's neobohemias. Low rent, space to work, and the promise of support, however temporary, for creative projects is attractive to artists. In providing these to artists, developers gain a low-risk, high reward investment that clears future sites of premium real estate of any previously existing marginalized populations. Artists become a "boots on the ground" avant-garde for developers, turning urban areas previously underserved by local government into the next most desirable place to live. The privatization of urban territory requires this involvement with the creative community, who represent a critical first-step in gentrification efforts. Working artists and other culture creators are also an important source of labor and marketing for developers. Both artists and developers share certain traits like flexible, entrepreneurial thinking, and a disregard for risk-aversion that allow them to succeed or fail in environments that are far from secure but that can be deeply rewarding. Lloyd quotes Holland Cotter of the New York Times, "Never has the American art world functioned so efficiently as a full-service marketing industry on the corporate model" (Lloyd, 2010, p.263). Is this true only in the art market, or in other art world sectors as well? What might contribute to the continued cooperation between artists and developers when the benefits to artists tend to be temporary at best, and philosophically often at adds? Discussions with others, artists and nonartists alike, lead me to believe that people in general are remarkably unfamiliar with the basic economic and political power structures that impact them. Bombarded by vast amounts information daily, that data isn't easily connected into clear and useful concepts that promote more critical thought regarding how we live and interact with others. Often the deluge of information has a dulling, and opposite effect.

As cultural and economic architects, neoliberals relentlessly espouse the virtues of small government while actually constructing something quite different. Philip Mirowski notes, “...mature neoliberalism is not at all enamored of the minimalist night-watchman state of the classical liberal tradition: its major distinguishing characteristic is instead a set of proposals and programs to infuse, take over, and transform the strong state, in order to impose the ideal form of society..." (Mirowski, 2013, p.40). Neoliberal global economics restructures social behavior and culture by replacing community and democratically focused citizens with self-interested individual investors whose decisions are governed by an unregulated market allegedly free of state intervention. Contrary to political talking points, neoliberal policy does not champion small government if that government in any way impedes the growth of the market. It promotes an aggressive shift toward managed governance that relentlessly advances "...highly optimistic claims about exceptional wealth 
creation, global opportunity and hybrid culture with emphases on the free market, unrestricted property rights, and self-reliance and opposition to welfare and redistribution" (Antonio, 2007, p.2). In this scenario, government is not concerned with the protection of democratically determined cultural space reflective of its citizenry, but instead concerns itself with creating culture and legislation that favors markets over people, and punishes those who will not, or cannot participate as investors.

The art market itself is a useful model to explain the current shift in policy toward neo-liberal society. It shares both philosophical and structural similarities with financial markets in that both are speculative and predictive but not wholly predictable, and both require investment in a yet unknown future performance of a product or service. Both markets have the seductive potential to generate great wealth quickly, and to experience "corrections" that leave investors vulnerable to financial loss. However, because it is such an accurate model for market-centered life, the art market is also limited as a model to explain the remaking of society along market lines, because it, like financial success in a neo-liberal society, exists more as a utopia. In theory, a market-centered global economy could offer some advantages under certain conditions, but pragmatically those conditions remain inaccessible to most people. Not everyone can afford to collect art. For most people, the acquisition of food and shelter consume the majority of time spent and money earned. While the art market itself is limited, the production of culture that it engenders is vast and critically important to changing how we view money, work, and even life itself as a commodity and measure of success. It is the production of culture, in which the art world excels, which is of the most interest to neoliberal policy makers, because neoliberal life requires creativity both in its design and implementation. What actually determines the financial success of individuals is something altogether different and remarkably predictable.

According to Milanovic in The Haves and the Have-Nots: A Brief and Idiosyncratic History of Global Inequality, two factors overwhelmingly explain a person's income. These factors, determined at birth, are citizenship and the income of one's parents. Statistically, effort is not a significant factor. Though for neoliberals, poverty is typically regarded as a function of effort, and the avoidance of poverty serves to motivate and control. Poverty's visibility and possibility train people to make market supporting decisions rather than decisions supporting the greater collective good (Milanovic, 2012, p.121) As Brown states in Edgework: Critical Essays on Knowledge and Power, "The political sphere, along with every other dimension of contemporary existence, is submitted to an economic rationality; or, put the other way around, not only is the human being configured exhaustively as homo oeconomicus, but all dimensions of human life are cast in terms of a market rationality" (Brown, 2005, p.40). Government and the state then exist only for the construction, development and expansion of a voracious and indifferent global market economy. The role of the art world in market-centered strategies is, most importantly, to create the culture of desire for private property and ownership that drives the sale of market products, including art. It could be argued that the 
art world exists as the sexy consort of an under the radar and visually elusive neo-liberal agenda. In Michigan, I would suggest that neo-liberalism is hiding in plain sight.

Detroit, Michigan, once ground zero of the North American auto industry and still home to General Motors, exemplifies the rapid shift toward the neoliberal privatization of urban space in the United States. Recent state legislation erodes and dismantles bedrock democratic processes, and unilaterally transfers local control of some financially distressed cities and school districts away from elected officials to governor appointed managers. These unelected managers are tasked with designing and implementing significant and on-going local economic turnarounds before returning control of a municipality or district to its previously elected local officials.

Emergency managers aren't new to Michigan, however the roles of appointed managers changed radically through congressional action taken in 2012 by Michigan's conservative Republican legislature with well-documented ties to outside political funding. At that time emergency managers were granted sweeping powers far beyond those of their predecessors. In a ballot initiative in November of 2012, the citizens of Michigan successfully voted to overturn these additional powers outlined in Public Act 4. Less than a month later, new legislation was reintroduced and signed by the governor. An even more aggressive bill than Public Act 4, the new legislation now included provisions prohibiting its rejection through a referendum. Despite clear opposition from the state's voters, Public Act 436 took effect in March of 2013 and granted unprecedented power to all emergency managers (see Michigan Legislative Website). These managers may now hire and terminate local government employees; negotiate, terminate or modify existing labor contracts; sell, lease or privatize local assets; revise contract obligations and change local budgets without local approval. They may also initiate municipal bankruptcy proceedings as well as hire support staff and consultants.

Beyond the striking level of personal power unilaterally granted to emergency managers in Michigan lies the fact that overwhelming public condemnation at the polls did nothing to alter the political goals of the Michigan state house. Conservative state politicians influenced by a wellfunded neoliberal economic agenda ignored voters and the democratic process. Mirowski, in Never Let a Good Crisis Go to Waste: How Neoliberalism Survived the Financial Meltdown, notes that managing an authoritarian state while maintaining at least the appearance of a functioning democracy is not an easy task: "This is a thorny problem for neoliberals; how to maintain their pretense of freedom as non-coercion when, in practice, it seems unlikely that most people would freely choose the neoliberal version of the state" (Mirowski, 2013, p.57).

Emergency managers regularly auction off public assets, liquidate public resources and transfer ownership of public enterprise to private investors with impunity. Conspicuously absent from the managers are plans for future financial stability that allegedly constituted the need for emergency managers in the first place. Plans to create jobs and alleviate unemployment for a 
working class population are not a priority. Reformation of Detroit's public schools by governor appointed managers continues to fail by state and national standards. The solution to all problems seems to involve, and privilege, the short-term liquidation and privatization of public assets. Little has changed to improve and secure the fiscal health of the cities and school districts in Michigan with emergency managers

The well-publicized potential sale of selected artworks from the Detroit Institute of Arts Museum to private corporations and investors illustrates this point more clearly. The purpose of such a sale would have been to partially repay creditors for massive debts accrued by the city over the last half-century, while ignoring the issues that created the debt in the first place. The cultural loss to Detroit by selling the art would have been incalculable, yet it has been suggested by some in the business community that Detroiters no longer deserve their art, having squandered their right to it with their failed economy. This echoes the neoliberal philosophy that poverty is the result of a lack of effort, rather than a set of circumstances, some chosen but many not. The list is long of liquidations and fire sales across Michigan that continue to move public enterprise into private hands while failing to provide the financial leadership promised to the state's most struggling urban communities.

The Detroit Free Press and Detroit News as well as other media organizations provide most of the scant information regarding emergency managers available to the public. Reviews of distressed municipalities and appointments of managers occur quietly and quickly, without public input. Increased speed and efficiency are the primary reasons given in support of the appointment of emergency managers and both are useful in the service to a neoliberal economic agenda whose outcomes might face far greater resistance were they more transparent. There is little awareness regarding emergency manager authority in communities without managers or significant minority populations. The appointment of emergency managers thus far has been confined to urban areas inhabited by minority populations, so the loss of elected and representative government in Michigan has largely affected only urban minority communities. Race and cultural indifference are significant factors influencing the relative ease with which emergency managers have been dispatched and installed. Michigan's white populations remain unaffected by the political disenfranchisement that the appointment of an emergency manager necessarily produces. Additionally, little information is available regarding the long-term ramifications of emergency manager privatization strategies, their suspension of democratic processes and the cultural implications of such actions. Michigan to date is the only state to enact such radical measures. This complicates an understanding of these strategies, and effectively muzzles efforts to mount strong and public opposition. The silence of the citizenry in a state historically known for its proud collective voice and democratic ideals raises important questions. Do Michigan's current economic policies foreshadow this type of economic legislation and disregard for democratic practices in other areas of the United States? Similar strategies are well underway worldwide. The World Bank, International Monetary Fund and 
other global lending institutions maintain established and well-documented regulations for loaning money to emerging countries with neoliberal economic strings attached (Steger \& Roy, 2010, p.19). The upward redistribution of wealth in neoliberal economies means that financial institutions will continue to amass and impose even greater influence over people's lives at the local level.

In Michigan, the political conditions and strategies described above are having a significant impact on the shifting of space and political power. The ease and efficiency with which Michigan's conservative government continues to strip its citizenry of their resources, rights and collective voice, deserves greater scrutiny. Philip Mirowski may offer a clue, "People do not generally imagine themselves trapped in a world that is upside down relative to what they think they know... at least in the contemporary world, most conventional notions of political protest themselves have been transformed and subverted by privatization and commercialization" (Mirowski, 2013, p.329). It is here that we return to the issue of cultural production and its connections to art and artists.

Integral to my work are the questions connecting art, space and democratic processes. How do communities develop and adapt to adverse economic conditions like the ones described above, which have the effect of breaking down support for the collective good in favor of accumulating personal wealth? How does and could art function within such conditions? What could its work be? Should artists be more mindful of ways their art functions in the world?

Doris Sommer writes, "A more practical response to the dangers would distinguish art that does damage from art that does good" (Sommer, 2014, p.30). This assumes a certain position on the apart of the artist and the viewer. Who is to say what distinguishes damaging art from good art? A better starting point might be to more critically locate ourselves within the spatial-political landscape regarding our personal goals amidst the goals of others, and to live and work more intentionally from that position. More than a career, pleasurable hobby or investment, art in the future may be pressed into even greater service to assist those the market increasingly fails to enrich. Art attracts, informs and affects viewers, but should it now strive to be something more and if so, how?

The art world both empowers and resists forces. As artists, how do we contribute or resist? This article discusses at length places where artists intentionally and otherwise aid in the remaking of culture to favor forces that many in the art world oppose, and most are aware of the unique ability that art has to raise awareness by attracting attention to an issue or idea. Jerry Vile is an artist in Detroit who last spring under cover of darkness installed a number of plastic vultures on the lawn of the Detroit Institute of the Arts to protest the threatened sale of artwork mentioned earlier in this article. His installation, unapproved by the museum, was removed the next day, but not before it was widely photographed by the media and passersby. Vile's work, and the work of others who refer to Detroit and Michigan politics, clearly raise awareness of issues and also express their opinions. Are there also places where art works 
beyond raising awareness of an issue, to change minds and effect cultural change?

Antanas Mockus is a Columbian born academic and politician known for his use of humor and games to influence and change the behavior of others. $\mathrm{He}$ has used art, particularly performance to not only raise awareness of an issue, but to also change minds and behavior. While he was the Mayor of Bogotá, Columbia, he replaced the traffic enforcement arm of the corrupt police force with mimes in an effort to stem the flood of traffic related pedestrian fatalities that occurred in the Columbian city (Sommer, 2014, p.24). The mimes were trained, and then paid to direct traffic and heckle pedestrians who failed to use the crosswalks as intended to safely cross the street. The program was very successful over time in reducing pedestrian fatalities, and additionally produced a change in how the city's inhabitants behaved while navigating heavy traffic on foot. Pedestrians joined with the mimes and began to actively participate in performing their own much safer travel habits. In this instance a government funded art project affected cultural change in a substantial and meaningful way. Its success in producing change was no doubt linked to its funding, but more importantly, it success was also due to its power to visually attract attention, then demonstrate a new way to approach a serious problem entrenched in everyday life in urban Bogotá.

The previous two art projects perform differently and have different goals, however they both share the ability to affect community and to express the idea of a collective. In this way, each of them could be seen as forces that both support and resist and perhaps most importantly illuminate and clarify. Art works to free difficult concepts from the murk of the abstract. Though art can be used to exert undue influence, it can also be employed to energize, empower and restore. Through the making of art, data becomes visible, awareness raised, questions posed and collective voices restored. As artists, we cannot explore, challenge and recreate the boundaries of our existence without the artistic and democratic space to do so. So in conclusion; how should we as artists locate ourselves and our work in a globalized world struggling with a new set of rules for survival? Is it important that we do so? I say it is.

\section{References}

Antonio, R.J., 2007. The Cultural Construction of Neoliberal Globalism. In: G. Ritzer, ed. The Blackwell Companion to Globalization. Blackwell Publishing. Available from: http://www.blackwellreference.com/public/book.html?id=g978140513274 99781405132749.

Benjamin, W., 1999. The Arcades Project: Exposé of 1935. Translated by H. Eiland \& K. McLaughlin. Cambridge, MA. \& London: Belknap Press.

Brown, W., 2005. Edgework: Critical Essays on Knowledge and Power. Princeton: Princeton University Press.

Deutsche, R., 2002. Evictions: Art and Spatial Politics. Cambridge: MIT Press.

Lloyd, R., 2010. Neo-Bohemia: Art and Commerce in the Postindustrial City. $2^{\text {nd }}$ ed. New York: Routledge. 
Michigan Legislative Website. Public Act MCL Search. [Online] Available from: http://www.legislature.mi.gov/(S(5wuimv45yl31vc55xje2emfd))/mileg.aspx?page $=$ PublicActs [Accessed: 21 April 2014].

Milanovic, B., 2012. The Haves and the Have-Nots: A Brief and Idiosyncratic History of Global Inequality. New York: Basic Books.

Mirowski, P., 2013. Never Let a Good Crisis Go to Waste: How Neoliberalism Survived the Financial Meltdown. London: Verso.

Sommer, D., 2014. The Work of Art in the World: Civic Agency and Public Humanities. Durham: Duke University Press.

Steger, M.B., \& Roy, R.K., 2010. Neoliberalism: A Very Short Introduction. Oxford: Oxford University Press. 
